\title{
The Effects of Premarital Education Promotion Policies on U.S. Divorce Rates
}

\author{
Tiffany L. Clyde \\ Brigham Young University - Provo \\ Jocelyn S. Wikle \\ Brigham Young University - Provo \\ Alan J. Hawkins \\ Brigham Young University - Provo \\ Spencer L. James \\ Brigham Young University - Provo, spencer_james@byu.edu
}

Follow this and additional works at: https://scholarsarchive.byu.edu/facpub

Part of the Other Social and Behavioral Sciences Commons

\section{Original Publication Citation}

Tiffany L. Clyde, Jocelyn S. Wikle, Alan J. Hawkins, and Spencer L. James. "The Effects of Premarital Education Promotion Policies on U.S. Divorce Rates.” Psychology, Public Policy, and Law.

\section{BYU ScholarsArchive Citation}

Clyde, Tiffany L.; Wikle, Jocelyn S.; Hawkins, Alan J.; and James, Spencer L., "The Effects of Premarital Education Promotion Policies on U.S. Divorce Rates" (2019). Faculty Publications. 4140.

https://scholarsarchive.byu.edu/facpub/4140

This Peer-Reviewed Article is brought to you for free and open access by BYU ScholarsArchive. It has been accepted for inclusion in Faculty Publications by an authorized administrator of BYU ScholarsArchive. For more information, please contact ellen_amatangelo@byu.edu. 


\title{
The Effects of Premarital Education Promotion Policies on U.S. Divorce Rates
}

\author{
Tiffany L. Clyde, Jocelyn S. Wikle, Alan J. Hawkins, and Spencer L. James \\ Brigham Young University
}

\begin{abstract}
Currently, 10 states have enacted policies to promote premarital education and counseling. However, no research has documented whether these policies have actually decreased divorce rates in implementing states. The purpose of this study is to assess the effects of premarital education promotion policies on divorce rates. First, we conducted an implementation study to understand how well each state implemented the policy. A combination of methods was used, including reviewing the legislative documents and archival records, as well as interviewing academics and key persons knowledgeable of the legislation. Following the implementation study, we conducted an evaluation study to analyze the effects of the policies on divorce rates. Divorce rate data were obtained from NCHS National Vital Statistics Reports (1988-2016) and analyzed using difference-in-difference estimation with state fixed effects. The results of the implementation study documented generally poor implementation; most implementing states had little formal, ongoing oversight of policy implementation. Results of the evaluation study suggest that simple passage of legislation was ineffective, but effectively implementing a policy was significantly associated with a $.5 \%$ decrease in the divorce rate. Follow-up analyses, however, with an event history approach suggested that the policies have not had a discernable impact on divorce rates. We conclude with a discussion of the results of the implementation and evaluation studies and make suggestions for future policy efforts and research.
\end{abstract}

Keywords: public policy, divorce, premarital education, marriage

Supplemental materials: http://dx.doi.org/10.1037/law0000218.supp

In the United States, approximately $40-50 \%$ of first marriages and $60 \%$ of second marriages end in divorce (Amato, 2010; Centers for Disease Control and Prevention, 2017; National Marriage Project, 2019). Although the divorce rate has declined from its peak in the early 1980s, it remains historically high, especially in the early years of marriage regardless of age, race, or cohort (Copen, Daniels, Vespa, \& Mosher, 2012; Kreider \& Ellis, 2011).

Because of the extensive amount of research documenting the negative effects of divorce on individuals, families, and children (Amato \& Anthony, 2014; McLanahan, Tach, \& Schneider, 2013)

This article was published Online First December 12, 2019.

(D) Tiffany L. Clyde, School of Family Life, Brigham Young University; (D) Jocelyn S. Wikle, Department of Economics, Brigham Young University; (D) Alan J. Hawkins and Spencer L. James, School of Family Life, Brigham Young University.

Jocelyn S. Wikle is now at BYU Center for Family Studies, Provo, Utah.

The current manuscript, which shares similar ideas and data, is a revised and improved version of Tiffany Clyde's master's thesis found here: https://scholarsarchive.byu.edu/etd/7514/. An adapted version of the thesis was presented at to the Research Advisory Council in December 2018. In addition, blog posts for the Institute of Family Studies (https://ifstudies .org/blog/do-premarital-education-promotion-policies-work) and The Relationship Educator blogs (http://relationshipeducator.org/blog/research/ do-premarital-education-promotion-policies-work/\#more-456) were written as adapted versions of the thesis.

Correspondence concerning this article should be addressed to Tiffany L. Clyde, School of Family Life, Brigham Young University, 2375 East 850 South, Springville, UT 84663. E-mail: Tiffany.clyde1@gmail.com and the economic impact on communities, states, and nation (Scafidi, 2008; Schramm, 2006), some governments have taken a special interest in public policies aimed at reducing family instability. For instance, some states have taken a preventative approach to reducing divorce by implementing premarital education promotion policies. To date, 10 states have passed some form of premarital education promotion policies. These policies encourage engaged couples to participate in premarital education courses to gain knowledge and learn skills to help strengthen the foundations of a marriage. Although previous research has documented the positive effects of participating in premarital education on strengthening marital relationships (Fawcett, Hawkins, Blanchard, \& Carroll, 2010; Stanley, Amato, Johnson, \& Markman, 2006), no research has documented whether premarital education promotion policies have actually increased the participation rate and subsequently decreased the divorce rate in the implementing states. Accordingly, the purpose of this study is to investigate the effectiveness of premarital education promotion policies on reducing divorce rates.

\section{Recent History of Divorce Trends and Laws in the United States}

Demographers and historians noted a spike in the divorce rate at the end of World War II, followed by two decades of relative stability (National Marriage Project, 2019; Wilcox, 2009). From the late 1960 s to the 1980 s, the divorce rate more than doubled, reaching its highest point in the early 1980s. Less than $20 \%$ of marriages in 1950 ended in divorce, but approximately $50 \%$ of 
marriages in 1980 did. Since the 1980s, divorce rates have declined modestly (National Marriage Project, 2019; Wilcox, 2009).

Several changes in divorce laws may be implicated in high divorce rates in the 1970s and 1980s. California was the first state to adopt no-fault divorce with the Family Law Act of 1969, which became effective January 1, 1970. Prior to no-fault divorce, couples would seek a divorce through the adversarial judicial system as a civil action by showing one of the parties was at fault on various grounds (e.g., adultery, abuse, abandonment, commission of a felony). Higher barriers to divorce meant marriages at marginal levels of quality were less likely to break up. No-fault divorce laws replaced the older laws with a proceeding for divorce on the grounds of irreconcilable differences. Within a decade, nearly every state had passed a no-fault divorce law resulting in a significant legal transformation in divorce (Wilcox, 2009), essentially providing unilateral divorce. New York was the exception until 2010. Currently, every state has adopted some variation of no-fault divorce.

In addition, over the past 50 years 32 states have foregone mandated waiting periods for divorce. Of those states that still have waiting periods, the modal waiting period is 6 months (DivorceSource.com, n.d.). Evidence suggesting that waiting periods significantly change the divorce rate is limited and mixed; if any effect exists, it is likely quite modest (Lee, 2013). (Note that major changes in divorce laws, such as no-fault divorce and shortened waiting periods, mostly occurred prior to the implementation of premarital education promotion policies, which limits their impact on our investigation here).

\section{Recent Marriage and Divorce Policy in the United States}

Because of the numerous financial, social, and psychological costs of divorce, some policymakers have been searching for direct policy mechanisms to decrease family instability and to increase individual and relational well-being for adults and children (Brotherson \& Duncan, 2004; Randles, 2017; Sawhill, 2014). (Of course, many other social and economic policies have indirect effects on family formation and stability.) The most well-known policy is the federal Healthy Marriage and Relationship Education initiative, a set of policies that have sought to promote healthy marriages and relationships as a part of federal welfare policy. Through this initiative, the federal Administration for Children and Families has provided significant grants (totaling \$1.1 billion from 2006 to 2019) to community organizations to support relationship education and family strengthening services targeting lower income individuals and couples (Hawkins, 2019; Randles, 2017). A review of the evaluation research on this initiative "reveals a large and serious body of rigorous evaluation work that shows promising successes, disappointing failures, and nuanced findings in between" (Hawkins, 2019). A handful of states (e.g., Oklahoma, Utah, Texas, Florida) have had parallel, ongoing state-level efforts to promote and support relationship education efforts, although Utah and Oklahoma are the only states that have maintained ongoing state-level support (Hawkins \& VanDenBerghe, 2014).

Additional legal efforts include adopting covenant marriage laws, which allow couples applying for marriage licenses to opt into a covenant marriage contract (Nock, Sanchez, \& Wright, 2008). The contract requires participating in formal premarital education, seeking marital counseling before filing for divorce, and an extended waiting period for divorce. However, currently only three states have adopted covenant marriage laws (i.e., Arizona, Arkansas, and Louisiana) and the proportion of couples who are choosing a covenant marriage appears to be very small (Nock et al., 2008).

\section{History of Premarital Education Promotion Policy}

Premarital education promotion policies have coincided with existing policies and community initiatives intended to strengthen marriages and reduce family instability. However, rather than being implemented at a federal level, premarital education promotion policies have been implemented at the state level. Studies suggest that only about one third of couples participate in premarital education or counseling (Stanley et al., 2006). Hoping to increase participation rates and thereby reduce family instability, 10 states have currently adopted premarital education promotion legislation: Florida (1998); Oklahoma (1999); Maryland (2001); Minnesota (2001); Tennessee (2002); Georgia (2004); South Carolina (2006); Texas (2007); West Virginia (2012), and Utah (2018). (At least six other states have considered but not passed premarital education promotion legislation: California, Connecticut, Hawaii, Iowa, Michigan, and North Dakota.) No studies have rigorously documented the impact of these policies on increases in premarital education, although two involved policy observers in two affected states estimated this figure at about 20\% (W. Doherty; K. Roberts, personal communications, 2016).

Although there are slight variations among the statutes, they have much in common. They provide incentives, typically in the form of marriage license discounts, for couples to participate in formal premarital education. The statutes also stipulate a specific number of hours in formal premarital education. There is more variability in the requirements regarding the educational content and who is authorized to provide approved premarital interventions.

Premarital education is generally defined as "an educational program with curriculum specifically designed for couples preparing for or seriously considering marriage," (Clyde, Hawkins, \& Willoughby, 2019, p. 3). Although there are differences between premarital education and counseling, the terms are often used interchangeably. (For purposes of brevity, we refer here to these policies as premarital education promotion, but all policies include couple counseling interventions, as well.) Both generally have a set curriculum that includes learning and practicing basic principles and skills for healthy marriages, such as effective communication (Clyde et al., 2019). Premarital interventions come in a variety of forms. One common form is programmatic curricula delivered by trained facilitators in face-to-face group settings. Most often, these are offered in religious settings by religious providers (Stanley et al., 2006). Both religious and secular forms of premarital education meet the requirements outlined in each state's legislation to promote premarital education.

\section{Public Policy Rationale}

Can government play a helpful role in strengthening marriages and reducing family instability? Government involvement in marriage, which is primarily viewed as a private domain, requires 
sufficient justification. According to Brotherson and Duncan (2004, p. 459), "The rationale for government efforts to strengthen marriage does not divide easily along political or ideological lines." What is the rationale for government intervention to attempt to strengthen marriages?

A theoretical framework for government involvement in efforts to strengthen marriage begins with ecological systems theory (Bronfenbrenner, 1979, 1992). According to this theory, the macrosystem, or the outermost layer in an ecology of influences on individual human development, is comprised of laws, cultural values, and customs that influence and shape features of all the other systems (Berk, 2000; Rosa \& Tudge, 2013). One part of the rationale for government intervention is the idea that policy can promote cultural-level shifts regarding marriage and divorce (Brotherson \& Teichert, 2001; Ooms, 1998). More specifically, government involvement in marriage sends the message that healthy marriages matter not only on a personal level, but for society as well (Gallagher, 2004; Ooms, 1998). An important goal of premarital education promotion policy, then, is to send stronger cultural signals that couples would do well to prepare effectively for marriage (Ooms, 1998).

A human service rationale for government involvement in marital matters derives from the considerable evidence that the family instability associated with divorce is, on average, detrimental to children's well-being. Research has repeatedly documented the associations between children's divorce experience and lower academic achievement, psychological adjustment, behavioral problems, and social competence (Amato, 2010; Amato \& Anthony, 2014; Frisco, Müller, \& Frank, 2007; McLanahan et al., 2013). Although children of high-conflict marriages may actually benefit from divorce (Amato \& Afifi, 2006; Booth \& Amato, 2001), most divorces come from marriages with a history of low-level conflict (James, 2015). Moreover, the effects of divorce continue to influence children of divorced parents well into adulthood (Amato \& Keith, 1991; Amato \& Sobolewski, 2001; Amato, 2010) and the repercussions of divorce can affect the next generation, as well (Amato, 1996; Amato \& Cheadle, 2005; Wolfinger, 2005). Although most adult children of divorce become happy, productive citizens (Amato, 2010; Amato \& Anthony, 2014), the effects of marital dissolution are, on average, associated with scoring lower on a variety of individual and relational well-being indicators for young children, adult children, and the next generation (Amato, 2010; Frisco et al., 2007; McLanahan et al., 2013). Accordingly, a stable, two-parent family appears to be the optimal environment for raising children to become healthy adults (Brotherson \& Teichert, 2001; Ooms, 1998; Sawhill, 2014; Waite \& Gallagher, 2002). If greater participation in premarital education can reduce family instability, it may improve the well-being of children.

The utilitarian and economic rationale for government involvement in marriage and divorce policy derives from the public costs associated with private choices, what economics call "externalities." The economic costs of a divorce for local, state, and national governments is conservatively estimated to exceed $\$ 33$ billion a year (Schramm, 2006). One study conservatively estimated that the annual cost of divorce and other forms of family instability in Texas to be $\$ 3.18$ billion (Schramm et al., 2013). Another economist estimated divorce and family instability cost taxpayers nationally at least $\$ 112$ billion per year (Scafidi, 2008). Moreover, family fragmentation is modestly associated with numerous social problems (e.g., drug use, delinquency, child abuse, domestic violence; Sawhill, 2014), which are difficult to calculate and include in the estimates. Of course, the short-term economic costs for the individuals directly involved are high too, with the average once estimated to be approximately $\$ 15,000$ (Michon, n.d.; Schramm, 2006). If premarital education policies can reduce family instability, then it will save taxpayers (and the individuals involved) money.

There is a political consideration, as well. That is, a return to some kind of fault-based divorce does not seem politically feasible because of the overwhelming public acceptance of divorce (Pew Research Center, 2017). A focus, then, on preventing the need for divorce presents a more politically palatable path. No public records indicate that premarital education promotion policies were pursued in direct response to no-fault divorce laws, but it is fully plausible that these policies were a response to such laws. (Implementing states generally had above-average divorce rates). Without rolling back popular laws that have made divorce easier to obtain, preventative efforts to reduce the need for divorce, such as incentives to invest in premarital education, have emerged in the wake of no-fault divorce.

We have outlined a general rationale for government interest in strengthening marriages and increasing family stability. But there is a more specific rationale for promotion of premarital education. The transtheoretical stages of change model (Prochaska, DiClemente, \& Norcross, 1992) helps us understand the stages people go through in preparing for important changes and highlights a unique openness to change in the action stage, a stage in which people are taking specific actions to achieve a goal. Formal premarital education for engaged couples can capitalize on this openness to change to increase the knowledge and skills needed for healthy relationships. Perhaps this openness to change is a crucial mechanism by which premarital education achieves its aims. Premarital interventions help couples assess their readiness for marriage, evaluate the quality of the match, align expectations and plans, improve relationship skills, and increase commitment to the marriage (Hawkins, 2015). Although many imagine engaged couples as having stars in their eyes, confidence in forever, and no significant problems, research paints a more complex picture (Clyde et al., 2019). Many couples enter into marriage with significant relationship problems, doubts, and ambiguous commitment (Lavner, Bradbury, \& Karney, 2012; Lavner, Karney, \& Bradbury, 2012).

A significant body of research suggests that premarital interventions can help couples strengthen communication skills, increase marital satisfaction, and reduce the early risk of divorce (Fawcett et al., 2010; Nock et al., 2008; Stanley, Amato, et al., 2006). In addition, participating in premarital interventions appears to help some couples identify red flags and make deliberate considerations about the future viability of their marriage (Stanley, 2001). There is also evidence that participation in premarital education is associated with a greater likelihood of seeking couple counseling later on to deal with marital problems (Williamson, Hammett, Ross, Karney, \& Bradbury, 2018; Williamson, Karney, \& Bradbury, 2019), and this association is stronger for low-income couples who face a higher risk for divorce (Williamson, Trail, Bradbury, \& Karney, 2014).

We have organized these rationales into a logic model that explains how adopting premarital education promotion policies 
could impact divorce rates and strengthen families, communities, and society (see Figure 1). In short, the model outlines how well-implemented policies will make more couples aware of the value of premarital interventions and providers. In turn, this awareness leads to greater participation in a program or counseling to learn basic principles for strong marriages and practice skills to build and sustain healthy relationships. Financial incentives-a discount on the marriage license fee-are built into the policies to provide gentle nudges to encourage greater participation in premarital interventions. Higher rates of participation yield betterprepared couples whose relational knowledge and skills increase the quality of the relationship and their commitment to it. Also, they are more likely to seek help if marital problems emerge down the road. It also prevents some high-risk marriages from forming when red flags are recognized. All this translates into fewer divorces in the early, high-risk years for divorce for states implementing these policies. Ultimately, this yields improved outcomes for individuals, couples, their children, communities, and society.

Conceptually, policy effects of premarital education policies likely operate as a two-stage process: Policy Initiation \& Implementation $\rightarrow$ Increase Premarital Education $\rightarrow$ Decrease Divorce (Intended Goal). In the first stage, policy initiation needs to be cemented with effective policy implementation to increase premarital education participation. Policy implementation can be exceedingly difficult (Pressman \& Wildavsky, 1973; Bardach, 1977), and if policy implementation efforts are weak, there may be no change in participation in premarital education. (We qualitatively evaluate policy features and implementation efforts to assess the strength of the first stage of the process.) Effective implementation leads to greater awareness and availability of premarital education opportunities that may change couples' likelihood of participating in premarital education. Then, in Stage 2, changes in premarital education participation may strengthen relationships and in turn reduce the incidence of divorce (Fawcett et al., 2010; Stanley, Amato, et al., 2006; Nock et al., 2008).

Ideally, data on the direct connection between couple awareness of premarital education, subsequent participation, and resulting divorce outcomes would be used. Unfortunately, such data are not available. Thus, although we cannot estimate each stage separately, we can measure the combined effect of policy implementation and couple information together. To estimate the impact of the policy on divorce behavior, we measure the effect of the policy on the final outcome (letting the intermediate outcomes remain implicit).

Despite the rationale presented here, there is still a debate among scholars and policymakers regarding whether government involvement in marriage and family matters is justified and effective (Brotherson \& Duncan, 2004; Randles, 2017). While this study cannot fully answer that broader question, it does have important implications for policymakers and scholars on the narrower question of whether state premarital education promotion policies are effective at reducing divorce. In addition, this study contributes to the ongoing push for evidence-based policy (Gueron \& Rolston, 2013; Haskins \& Margolis, 2015).

\section{Method}

To assess the effects of premarital education promotion policies designed to strengthen marriage and reduce divorce, we employed difference-in-difference estimation. Before this set of analyses, however, it was important to assess how effectively premarital education promotion policies have been implemented. Passing legislation without effective implementation of the law is unlikely to produce intended effects. Accordingly, first we outline our methods for obtaining documentation about implementation. Then we outline our methods for testing empirically the potential impact of these policies.

\section{Implementation Study}

The purpose of the implementation study was to answer several questions regarding how effectively the premarital education promotion policies were implemented in each state. More specifically, we sought to answer the following questions: What are the core

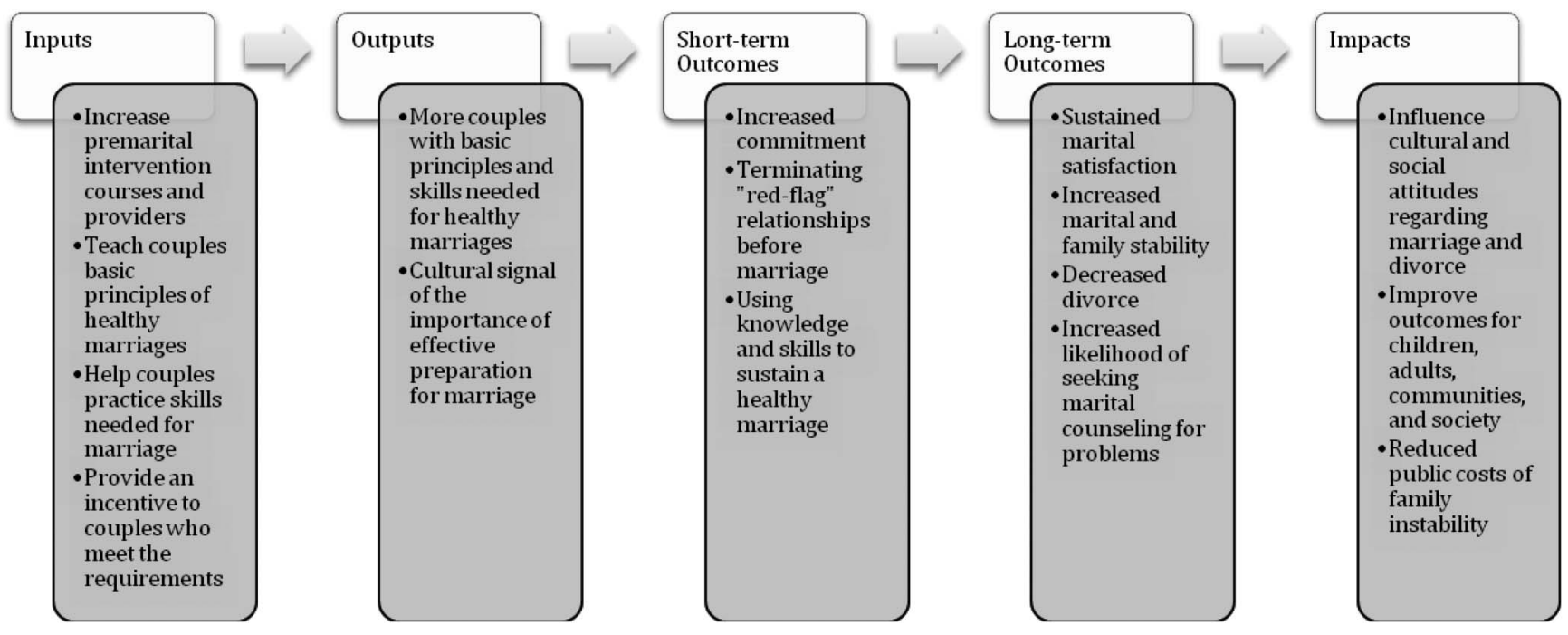

Figure 1. Logic model for adopting premarital education promotion policies. 
elements of the legislation? How is/was the legislation implemented? How is the policy being marketed or advertised? Is there a formal entity charged with oversight of the policy? Is there ongoing attention from this entity charged with promoting and monitoring the policy? Is there funding allocated to promote the policy and premarital education? Are there any data available on premarital education participation rates? Did the legislation require a formative and/or an outcome evaluation? Was a formative and/or outcome evaluation conducted?

Unfortunately, data on participation rates in premarital education are not collected in any formal manner or by states. As such, we were not able to document whether the premarital education promotion policies have actually increased premarital education participation rates. And although copies of the legislation are available to the public, the documents alone do not provide a complete answer to how the bills were implemented and the effectiveness of the implementation. Accordingly, to answer these questions we used a combination of methods, including reviewing the legislative documents, reviewing archival records, and interviewing academics and key persons associated with the bills. Legislative records were obtained through each state's legislative website and reviewed to document basic features of the bills, including required number of hours a couple must spend participating in premarital education and the marriage license discount. The remaining questions were answered by conducting interviews by e-mail or a phone with academics, county clerks, and key persons knowledgeable about the bills. Again, the purpose of the implementation study was to understand how well each bill has been implemented. Based on the implementation study, we made a qualitative judgment on the effectiveness of each state's efforts to implement the policy.

\section{Evaluation Study}

Data. We use annual divorce rates before and after policy implementation to empirically evaluate premarital education policy effects. The outcome variable of interest is annual divorce rates at the state level. We obtained annual state-level panel data for all 50 states. Washington, DC was not included in the analyses, given that population demographics are atypical and include many outliers, such as a lower marriage rate. In addition, Washington, DC cannot implement a premarital education promotion policy without action by the U.S. Congress, which does not seem likely. Unless otherwise noted, all analyses cover the period between 1988 and 2016. The first state to implement a premarital education promotion policy was Florida in 1998. To account for preexisting statespecific trends, we have included at least 10 years of preintervention data for each state. For most states, excluding West Virginia (passed in 2012), there is a decade-long period after the implementation of the premarital education promotion policy available for analysis. Utah was considered a nonimplementing state in both studies because the policy was passed only in 2018 and not implemented until October 2019.

Administrative data on divorce rates were obtained for each state by year from Vital Statistics of the United States. Data from 1988 to 1998 were collected and entered by Justin Wolfers from annual additions of Vital Statistics (see Wolfers, 2006); we made use of this data file. Replication of data from 1999 to 2016 was relatively easy since Wolfers outlined his process and generously made the data accessible to the public. Accordingly, we extended the sample to 2016 by entering divorce rate data from annual additions of Vital Statistics.

The predictors of divorce rates are implementing versus nonimplementing (premarital education promotion policy), core elements of the legislation (e.g., required dosage of intervention, marriage license discount, required curricula or topics), and quality of implementation. Many of the predictors were coded as dichotomous variables. States that had implemented the policy were coded as a 1 and nonimplementing states were coded as a 0 . This variable served as a dummy variable for the analyses.

Implementing states that required more than $8 \mathrm{hr}$ of instruction were coded as a 1 , whereas all other states (implementing and nonimplementing) were coded as a 0 . This cutoff was selected as several meta-analyses of relationship education programs (all types) suggest that moderate-dosage interventions (8-20 hr) produce somewhat stronger effects (Hawkins, Blanchard, Baldwin, \& Fawcett, 2008; Hawkins, Stanley, Blanchard, \& Albright, 2012). To test whether dosage effects emerge from lower intensities without a linearity assumption, we used an additional dummy to test whether lower dosages, or between 1 and $7 \mathrm{hr}$, produce effects compared to nonimplementing states. This approach also allows us to examine whether there are important thresholds in dosage that make a difference.

Similarly, states that offered a discount from the marriage license fee greater than $\$ 47.50$ (the average of the discounts offered) were coded as a 1 , whereas all other states (implementing and nonimplementing) were coded as a 0 . A cutoff of $\$ 47.50$ was used because it was hypothesized that larger discounts may lead to greater levels of participation. An additional dummy was used to test whether states with discounts less than $\$ 47.50$ produce effects compared to nonimplementing states. Again, this approach allowed us to examine whether there are important thresholds in the amounted discounted.

Another predictor was created based on the total number of required curricular topics to be covered as outlined in the policies, with a range from 0 to 6 . We hypothesized that the total number of required curricular topics is highly correlated with dosage. Greater coverage of important topics could indicate more effective programs.

Finally, a quality of implementation (effectiveness) variable was coded using a 4-point scale ranging from 0 (nonimplementing) to 3 (very effective). An implementing state's policy was considered ineffective if no formal oversight was outlined or occurred. Similarly, a state's policy was considered somewhat effective if some formal oversight was outlined in the policy and occurred or if no formal oversight was outlined but formal oversight occurred. The policy was considered very effective if formal oversight was outlined in the policy, oversight occurred, and funding was allocated to help with the implementation. As with other variables, qualitative judgments were made to create and code these items based on the implementation study. The effectiveness of implementation in this study was based on a state outlining formal oversight and allocating funding in the policy as well as the occurrence of actual oversight and implementation. If they are not effectively implemented, it is unlikely that the premarital education promotion policies would have an impact on divorce rates.

In addition, because this study necessarily uses a quasiexperimental design to evaluate policy and subsequent divorce 
rates — only observing implementation of policies - it was important to include a set of control variables in our analyses. Accordingly, the following variables were collected at the state level by year using Current Population Survey data (Flood, King, Rodgers, Ruggles, \& Warren, 2018) and used as controls in the analyses: percent of the population who identify as Black, White, and Hispanic; percent poverty; percent with bachelor's degree; real gross domestic product (GDP); median household income (in current dollars); median age of the population; and percent of the population that is married (to control for variation in the divorce rate denominator). These variables were all obtained from 1988 to 2016. Fixed effects models only account for variables that are stable over time. As such, the items mentioned above were included as controls because these demographic indicators have not only changed significantly in the last 30 years but potentially have changed in dissimilar ways across states.

Divorce rates, particularly measurement issues regarding divorce, require further explication. More specifically, divorce statistics are often quite controversial due to several inconsistencies in measurement (see Amato, 2010; Amato, n.d.; Birch, Weed, \& Olsen, 2004; Kennedy \& Ruggles, 2014). Multiple entities gather data on the divorce rate, but not in any prescribed manner. Typically, counties track the number of divorces granted and then divide these aggregate figures by state population estimates to derive the rate of divorces granted per 1,000 total population. However, some counties are not included in these estimates. Furthermore, California, Louisiana, and Indiana, do not report divorce rates at all. Consequently, divorce rates statistics are incomplete and somewhat controversial. Despite these limitations, the annual divorce rates included in all analyses are considered the best estimates of divorce rates available by family demographers. (Note that we made several attempts to replicate the numbers estimated by Kennedy and Ruggles [2014] to make the Census Bureau's American Community Survey [ACS] and National Center for Health Statistics (NCHS) divorce-rate statistics comparable. However, we could not replicate their estimates, so we did not proceed in that manner). We also reached out to several researchers at the Census Bureau for additional assistance and were informed that due to several statistical and methodological differences, NCHS and ACS data were not intended to be compatible or comparable. See Elliot, Simmons, and Lewis (2010) for a discussion on marital event items in ACS and NCHS. ACS estimates of divorce rates appear to be inflated.

Analysis approach. To estimate the effect of premarital education promotion policies on divorce rates, we use a difference-indifference model, which compares the divorce rates in each implementing state pre- and postimplementation. We focus on reduced form estimates, which can be interpreted as an intent-to-treat estimates. In quasi-experimental analyses, we used difference-indifference estimation using nonimplementing states as a comparison group and implementing states as a treatment group. Because divorce rates vary among states, the model calculates the normal difference in the divorce rates, or the treatment effect, between the implementing and nonimplementing states, or the difference that would exist without the policy.

We used a balanced panel with all states from 1988 to 2016. Difference-in-difference estimation requires data measured from all states with divorce-rate data at multiple time periods before and after the premarital education promotion policy was implemented.
Variation in the data comes from the fact that the nine states with premarital education policy promotion implemented the policies at varying times and enacted legislation with different dosage requirements, fee discounts, and so forth. In addition, there was variation in implementation efforts across states. The fact that the states implemented their legislation at varying times helps us identify the effects of the policy. We used the comparison group and the parallel trends assumption to account for any time-specific macro effects that may have shifted divorce rates for all states. An example of a macro effect on divorce rates between 1988 and 2016 would be the economic recession in 2008 .

In addition, including state-level fixed effects allowed us to account for unobserved state characteristics that are relatively fixed over the sample period. Controlling state fixed effects is important for mitigating problems associated with endogeneity. In particular, one could argue that states that experienced a higher divorce rate would be somewhat more likely to pass premarital education promotion policies. However, controlling for state fixed effects isolates changes in divorce rates relative to the state's previous divorce rate, thus minimizing endogeneity concerns.

We estimate the basic reduced form model as follows:

$$
D_{i t}=\alpha+\beta \text { PremaritalEd }_{i t}+\theta_{j} \cdot X+\alpha_{i}+\varepsilon_{i t}
$$

We represent divorce rates for state $i$ in year $t$ as the dependent variable. The variable PremaritalEd $d_{i t}$ indicates whether the state has a premarital education policy in effect at year $t$. The vector $X$ contains demographic and economic control variables (including real GDP, median income, average age of the population, percent Black, White, and Hispanic, percent of the population with at least a bachelor's degree, and percent of the population who are married). We separated the unobservable effects into a state-specific unobservable effect on divorce $\alpha_{i}$ and an idiosyncratic exogenous factor $\varepsilon_{i t}$. We assumed the state-specific unobserved effect was the same regardless of the divorce rate, and assumed the idiosyncratic exogenous factor was independent of the policy and other covariates. All data cleaning and analyses were conducted using Stata 15.1 software (StataCorp, 2017).

\section{Results}

\section{Implementation Study}

Nine states have currently implemented some form of premarital education promotion policies (Florida, Georgia, Maryland, Minnesota, Oklahoma, South Carolina, Tennessee, Texas, and West Virginia). (Utah's policy has not yet been fully implemented.) Using a combination of methods, as described above, we sought to understand the features of each statute and how the policies were implemented in each state. Each statute had unique language. Accordingly, we begin outlining several defining elements of the policies and describe briefly the differences between the policies. We conclude this section with an outline of how well the policies were implemented in their states. Notably, there is no evidence to suggest that the policies have been amended to improve them since the bills have been passed. A summary of the key elements of the policies can be found in Table 1. (For more detailed summary of each state's policy and implementation, refer to the online supplemental material). 


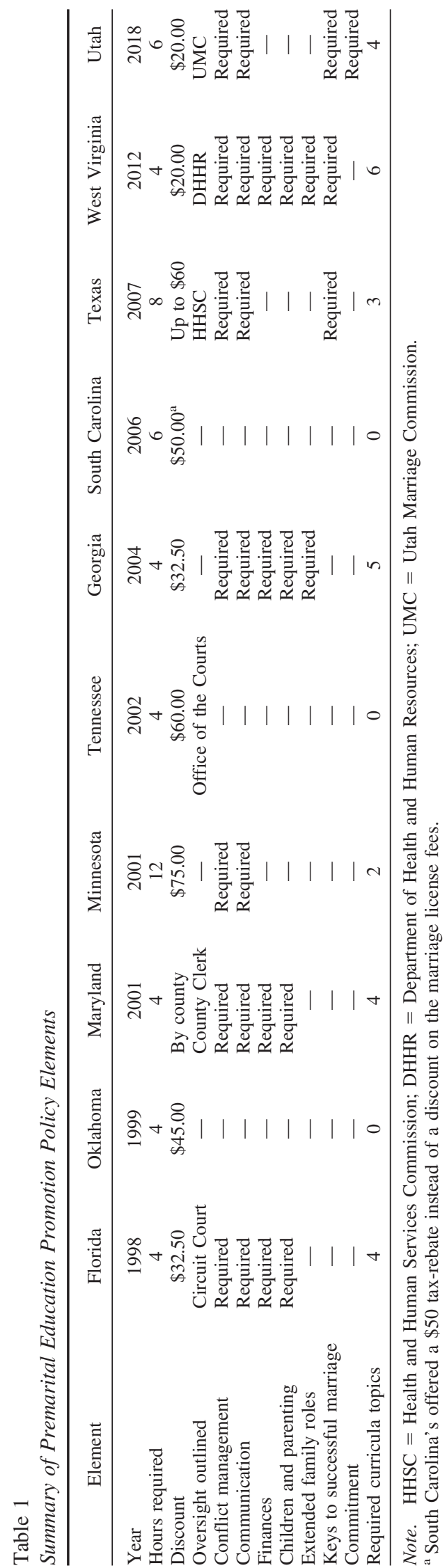

Premarital education and counseling. It is important to note that many of the policies use language that does not distinguish between premarital counseling and premarital education. Some policies specify only premarital counseling (Oklahoma) or premarital education (Minnesota, Georgia, Texas, and West Virginia). On the other hand, Florida, Maryland, Tennessee, and South Carolina use more ambiguous language such as premarital preparation course throughout the document. Thus, there is some doubt whether those states allow couples to participate in just premarital counseling, premarital education, or both. It appears that for some states content coverage is more important than the provider and delivery format.

Dosage. Each of the premarital education promotion policies specified the number of hours a couple should spend participating in a premarital intervention, with the majority of the states (six) requiring a couple spend a minimum of $4 \mathrm{hr}$ in formal premarital education.

Incentive. Eight of the states offered couples who completed a premarital intervention course a discount on their marriage license fee, ranging from $\$ 20$ to $\$ 75$. South Carolina's policy provides the couple with a $\$ 50$ tax rebate instead of a discount on the marriage license fee, which may be a less enticing incentive mechanism.

Provider. All of the statutes specified requirements regarding who could conduct or offer a premarital counseling or education program. Although there is variation in the exact language between the policies, generally, a premarital counseling or education program must be conducted by a health professional (e.g., a psychologist, marital and family therapist, professional counselor, or social worker licensed by the state), an official representative of a religious institution, or a trained marriage educator.

Content. Minnesota was the only state that required the use of a premarital inventory (Larson, Newell, Topham, \& Nichols, 2002) in addition to education- and skills-based premarital education and counseling. Most statutes included clauses specifying the required curriculum to be covered in the qualifying premarital education or counseling programs. Possible curriculum topics include conflict management, communication skills, finances, children and parenting responsibilities, extended family roles, and key components of a successful marriage. Three states (Oklahoma, Tennessee, and South Carolina) did not specify required subjects to be covered in the qualifying premarital education or counseling program.

Oversight and implementation. Overall, premarital education promotion policies were not effectively implemented. Five states (Florida, Maryland, Tennessee, Texas, and West Virginia) appointed a responsible entity to oversee and implement the policy. Florida's policy required the circuit courts to create and maintain a roster of course providers in their jurisdictions; many still maintain a roster. The policy also made the Florida State University Center for Marriage and Family responsible for determining the efficacy of different premarital preparation courses and the overall policy and added a sunset clause should the policy not reach its intended goals. However, there is no evidence to suggest that this fully occurred (see the online supplemental material). Maryland's policy also made the circuit courts responsible for creating and maintaining rosters of area course providers, however, efforts to locate such rosters suggest that they do not exist (see the online supplemental material for additional information). 
Maryland's policy did not include oversight of the efficacy of the course or the legislation. On the other hand, Tennessee's policy made the Administrative Office of the Courts responsible to report on the effectiveness of the policy and the impact of the fees imposed in the policy. There is no evidence to suggest that an evaluation occurred or a report was published. In Texas, the Health and Human Services Commission (HHSC) was responsible for maintaining an Internet website of course providers. The website continues to be maintained. West Virginia's premarital education promotion policy made the Department of Health and Human Resources responsible for maintaining an Internet website of course providers. Efforts to locate the roster of course providers suggest that one existed previously, but a current website could not be located.

Although five states appointed a formal oversight entity with some level of responsibility, interviewing academics and key persons associated with the bills suggested that little formal oversight occurred. And, if there was formal oversight, it was often shortlived. (See the online supplemental material for detailed accounts.) On the other hand, several states did not create formal oversight in their bills, but interviews with key personnel suggest that some oversight occurred. For instance, the legislator who sponsored the bill in Minnesota worked with the county clerks to provide a 1-year postimplementation estimate of participation rates and the estimated costs and benefits to the state (see the online supplemental material).

Texas was the only implementing state that had formal oversight and funding for several years. The Texas HHSC had initial responsibility for implementing the bill. HHSC created 11 regions and hired a small staff to implement the policy in each region, including training facilitators, offering workshops, advertising the policy (ads, fliers, billboards, radio, etc.), and providing classroom supplies. Funding started in late 2007 and ended in 2011 due to state budget cutbacks as a result the Great Recession. Although funding has ended, the policy continues to be implemented on a smaller scale and on a less formal basis. There is a volunteer network of unpaid trained facilitators who continue to offer premarital education and counseling courses.

Although formal oversight and implementation was minimal in most implementing states, we became aware of some informal implementation in many states. (The online supplemental material contains a more detailed account of informal implementation.) For instance, First Things First in Chattanooga, TN, has heavily marketed the policy to couples, resulting in a number of couples taking advantage of the classes they offer on a monthly basis. These informal implementation efforts have had a signaling effect. In other words, although formal government implementation has been minimal, informal efforts have resulted in increased awareness of the policy and the discount offered to couples who complete premarital education as outlined in each state's policy.

\section{Evaluation Study}

Descriptive statistics and correlation analysis. Figure 2 plots the trends in divorce rates, separating implementing and nonimplementing states. As this figure suggests, the divorce rate steadily declined in implementing and nonimplementing states, even prior to the passage of premarital education promotion policies. (For a discussion of why divorce rates have been steadily declining in the United States for 40 years, see Wilcox, 2009). Implementing states had notably higher divorce rates compared to nonimplementing states both before and after the implementation of the policies. However, trends appear similar during the prepolicy period. The gap between implementing states and non-

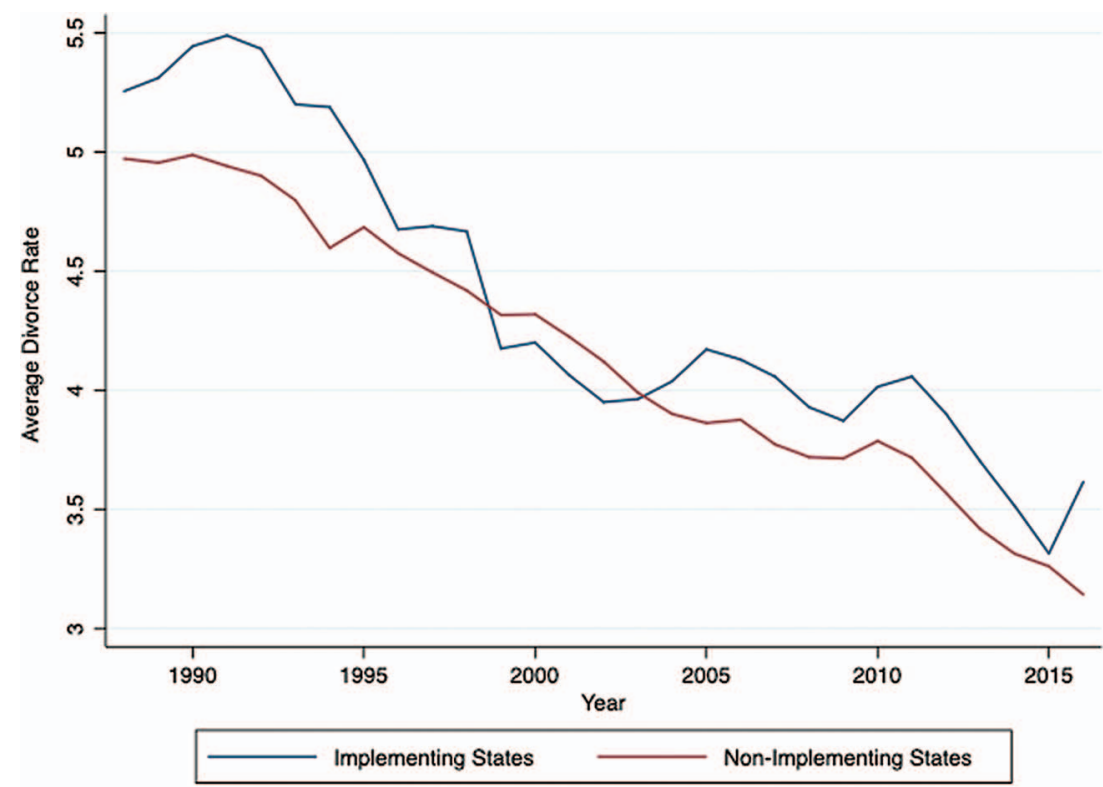

Figure 2. Average divorce rates in implementing and nonimplementing states from 1988-2016. California, Georgia, Hawaii, Indiana, Louisiana, and Minnesota were missing at least 10 years of divorce rate data and Oklahoma was missing 5 years due to changes in reporting requirements. See the online article for the color version of this figure. 
implementing states appears to narrow after the mid-1990s, perhaps as a result of policy implementation. However, this may also be attributed to the fact that several implementing and nonimplementing states stopped reporting divorce rate data to the Bureau of the Census starting in the late 1990s and early 2000s and are therefore unaccounted for when calculating raw averages. Additional descriptive statistics on divorce rates and state-level control variables are provided in Table 2 for implementing states and Table 3 for nonimplementing states. Over the panel, marriage rates declined, suggesting that fewer people were at risk for divorce later in the sampling period. Education levels and a shift toward an older population may also have contributed to falling divorce rates over time.

Figure 3 graphs trends in divorce rates in implementing states prior to and after the implementation of the premarital education promotion policies. Oklahoma, the second state to implement the policy, started and ended with the highest divorce rate. Overall, the implementing states experienced a steady decline in their average divorce rate, including prior to policy implementation.

Bivariate correlations can be found in Table 4. In regard to state-level control variables, median age $(r=-.34)$, median income $(r=-.53)$, real GDP $(r=-.35)$, percent of the population that is married $(r=.33)$, percent of the population with a bachelor's degree $(r=-.56)$, and percent poverty $(r=.26)$ were all significantly $(p<.001)$ associated with the divorce rate.
Having a policy was significantly and negatively associated with the divorce rate, $r=-.08, p<.01$. Several elements of the policy, namely the amount discounted $(r=-.14)$, the number of curricula or topics required $(r=-.09)$, and the effectiveness of implementation $(r=-.05)$ were also significantly $(p<.05)$ associated with the divorce rate.

There were several high correlations among state-level control variables. For instance, the percent of the population with a bachelor's degree and median income were significantly correlated, $r=$ $.83, p<.001$. Although all the high correlations among the state-level control variables made theoretical sense, they indicated the possibility of multicollinearity within the data. In addition, all of the elements of the policy were highly correlated. Given the dichotomous nature of many of these variables, this was not surprising. Nonetheless, we proceeded to check for multicollinearity using the "collin" command in Stata. All state-level variables were below a variance inflation index (VIF) value of .10 and given their nature as control variables, concerns regarding their influence on the analyses would be minimal (Allison, 2012). The dichotomous dummy variable for implementing versus nonimplementing states had a VIF of 15.10. All other elements of the policy had acceptable VIF values. Accordingly, given the possible multicollinearity among the dummy variables, we proceeded to run one regression with the dummy variable as the only predictor, as we were interested in whether or not having a policy alone was

Table 2

Descriptive Statistics of Divorce Rates and State-Level Control Variables for Implementing States

\begin{tabular}{|c|c|c|c|c|c|c|c|c|c|c|c|}
\hline Year & $\begin{array}{c}\text { Avg. } \\
\text { divorce rate } \\
\text { (all states) }\end{array}$ & $\begin{array}{c}\text { Avg. } \\
\text { divorce rate }\end{array}$ & $\begin{array}{l}\text { Median } \\
\text { income }\end{array}$ & $\begin{array}{l}\text { Median } \\
\text { age }\end{array}$ & $\begin{array}{c}\text { Real GDP } \\
\text { (in thousands) }\end{array}$ & $\%$ married & $\begin{array}{l}\% \text { with } \\
\text { bachelor's } \\
\text { degree }\end{array}$ & $\%$ Hispanic & $\%$ White & $\%$ Black & $\%$ poverty \\
\hline 1988 & 5.06 & 5.25 & 25.78 & 34.5 & 121,686 & .46 & .05 & .08 & .74 & .16 & .16 \\
\hline 1989 & 5.02 & 5.31 & 26.39 & 34.4 & 129,526 & .45 & .05 & .08 & .74 & .16 & .16 \\
\hline 1990 & 5.01 & 5.44 & 27.85 & 34.9 & 137,397 & .45 & .05 & .08 & .74 & .17 & .17 \\
\hline 1991 & 5.06 & 5.48 & 27.68 & 35.0 & 143,163 & .45 & .05 & .08 & .73 & .17 & .17 \\
\hline 1992 & 5.00 & 5.43 & 27.75 & 35.3 & 152,368 & .45 & .13 & .08 & .73 & .17 & .17 \\
\hline 1993 & 4.87 & 5.2 & 29.15 & 34.9 & 161,829 & .44 & .13 & .08 & .72 & .17 & .17 \\
\hline 1994 & 4.71 & 5.19 & 30.37 & 34.9 & 174,159 & .44 & .14 & .08 & .73 & .17 & .17 \\
\hline 1995 & 4.74 & 4.97 & 31.57 & 34.8 & 184,843 & .44 & .14 & .07 & .74 & .17 & .17 \\
\hline 1996 & 4.59 & 4.68 & 33.26 & 35.0 & 197,864 & .43 & .14 & .07 & .73 & .16 & .17 \\
\hline 1997 & 4.53 & 4.69 & 35.24 & 35.3 & 212,835 & .43 & .15 & .08 & .73 & .17 & .16 \\
\hline 1998 & 4.47 & 4.67 & 37.23 & 35.5 & 230,658 & .45 & .15 & .08 & .72 & .16 & .17 \\
\hline 1999 & 4.21 & 4.18 & 38.68 & 36.1 & 256,444 & .44 & .16 & .08 & .72 & .16 & .16 \\
\hline 2000 & 4.30 & 4.2 & 40.18 & 36.3 & 262,223 & .45 & .16 & .08 & .72 & .16 & .16 \\
\hline 2001 & 4.20 & 4.06 & 40.54 & 36.1 & 271,449 & .44 & .17 & .11 & .70 & .16 & .16 \\
\hline 2002 & 4.09 & 3.95 & 41.42 & 36.0 & 284,709 & .43 & .17 & .11 & .69 & .16 & .16 \\
\hline 2003 & 3.98 & 3.96 & 41.17 & 36.3 & 300,217 & .44 & .18 & .09 & .71 & .16 & .16 \\
\hline 2004 & 3.92 & 4.04 & 42.87 & 36.4 & 323,214 & .44 & .18 & .09 & .70 & .16 & .16 \\
\hline 2005 & 3.91 & 4.17 & 44.31 & 36.9 & 347,472 & .43 & .18 & .10 & .70 & .16 & .16 \\
\hline 2006 & 3.92 & 4.13 & 46.20 & 37.0 & 361,210 & .43 & .18 & .10 & .69 & .17 & .17 \\
\hline 2007 & 3.81 & 4.05 & 48.32 & 36.9 & 391,116 & .43 & .18 & .10 & .68 & .17 & .17 \\
\hline 2008 & 3.75 & 3.93 & 46.91 & 37.1 & 398,266 & .42 & .19 & .10 & .68 & .17 & .17 \\
\hline 2009 & 3.74 & 3.87 & 47.20 & 36.9 & 385,159 & .42 & .19 & .11 & .68 & .17 & .17 \\
\hline 2010 & 3.82 & 4.01 & 46.46 & 37.6 & 400,958 & .42 & .20 & .11 & .67 & .17 & .17 \\
\hline 2011 & 3.77 & 4.05 & 48.83 & 37.6 & 420,636 & .42 & .20 & .11 & .66 & .17 & .17 \\
\hline 2012 & 3.62 & 3.9 & 51.01 & 37.9 & 429,405 & .42 & .20 & .11 & .66 & .17 & .17 \\
\hline 2013 & 3.46 & 3.7 & 49.42 & 38.1 & 461,835 & .42 & .21 & .12 & .66 & .17 & .17 \\
\hline 2014 & 3.34 & 3.51 & 52.04 & 38.2 & 484,138 & .41 & .21 & .11 & .65 & .17 & .17 \\
\hline 2015 & 3.26 & 3.31 & 55.55 & 38.3 & 498,027 & .41 & .21 & .12 & .65 & .17 & .17 \\
\hline 2016 & 3.22 & 3.61 & 56.42 & 38.4 & 509,013 & .41 & .22 & .13 & .64 & .17 & .17 \\
\hline
\end{tabular}

Note. Avg. = average; GDP $=$ gross domestic product. Implementing states are Florida, Georgia, Maryland, Minnesota, Oklahoma, South Carolina, Tennessee, Texas, and West Virginia. 
Table 3

Descriptive Statistics of Divorce Rates and State-Level Control Variables for Nonimplementing States

\begin{tabular}{|c|c|c|c|c|c|c|c|c|c|c|c|}
\hline Year & $\begin{array}{l}\text { Avg. } \\
\text { divorce rate } \\
\text { (all states) }\end{array}$ & $\begin{array}{l}\text { Avg. } \\
\text { divorce rate }\end{array}$ & $\begin{array}{l}\text { Median } \\
\text { income }\end{array}$ & $\begin{array}{l}\text { Median } \\
\text { age }\end{array}$ & $\begin{array}{c}\text { Real GDP } \\
\text { (in thousands) }\end{array}$ & $\%$ married & $\begin{array}{l}\% \text { with } \\
\text { bachelor's } \\
\text { degree }\end{array}$ & $\%$ Hispanic & $\%$ White & $\%$ Black & $\%$ poverty \\
\hline 1988 & 5.06 & 4.97 & 27.07 & 34.0 & 108,079 & .45 & .05 & .05 & .82 & .08 & .13 \\
\hline 1989 & 5.02 & 4.96 & 28.95 & 34.2 & 101,534 & .45 & .06 & .05 & .82 & .08 & .12 \\
\hline 1990 & 5.01 & 4.99 & 31.20 & 34.3 & 106,719 & .45 & .06 & .05 & .82 & .08 & .12 \\
\hline 1991 & 5.06 & 4.94 & 31.20 & 34.4 & 110,068 & .44 & .06 & .06 & .81 & .08 & .13 \\
\hline 1992 & 5.00 & 4.90 & 31.26 & 34.3 & 115,930 & .44 & .14 & .06 & .81 & .08 & .13 \\
\hline 1993 & 4.87 & 4.79 & 31.82 & 34.4 & 121,119 & .44 & .14 & .06 & .81 & .08 & .13 \\
\hline 1994 & 4.71 & 4.60 & 31.94 & 34.3 & 129,238 & .43 & .15 & .06 & .81 & .09 & .14 \\
\hline 1995 & 4.74 & 4.68 & 34.33 & 34.7 & 136,310 & .44 & .15 & .06 & .82 & .08 & .13 \\
\hline 1996 & 4.59 & 4.58 & 35.62 & 34.6 & 144,424 & .43 & .15 & .06 & .80 & .09 & .13 \\
\hline 1997 & 4.53 & 4.49 & 37.10 & 34.8 & 154,127 & .43 & .16 & .07 & .79 & .09 & .13 \\
\hline 1998 & 4.47 & 4.42 & 39.71 & 35.2 & 170,088 & .43 & .16 & .07 & .79 & .09 & .12 \\
\hline 1999 & 4.21 & 4.31 & 40.71 & 35.1 & 180,708 & .43 & .16 & .08 & .78 & .09 & .12 \\
\hline 2000 & 4.30 & 4.32 & 41.21 & 35.2 & 192,087 & .43 & .17 & .08 & .77 & .09 & .11 \\
\hline 2001 & 4.20 & 4.22 & 42.77 & 35.9 & 197,133 & .43 & .17 & .09 & .76 & .09 & .11 \\
\hline 2002 & 4.09 & 4.12 & 42.69 & 36.1 & 203,486 & .43 & .18 & .10 & .75 & .09 & .11 \\
\hline 2003 & 3.98 & 3.99 & 43.89 & 36.0 & 219,850 & .43 & .18 & .09 & .76 & .09 & .12 \\
\hline 2004 & 3.92 & 3.90 & 44.85 & 36.2 & 226,218 & .43 & .18 & .09 & .75 & .09 & .12 \\
\hline 2005 & 3.91 & 3.86 & 46.64 & 37.0 & 244,867 & .43 & .18 & .09 & .75 & .09 & .12 \\
\hline 2006 & 3.92 & 3.86 & 48.78 & 36.0 & 265,064 & .43 & .18 & .09 & .75 & .09 & .12 \\
\hline 2007 & 3.81 & 3.77 & 50.82 & 36.9 & 276,160 & .43 & .19 & .09 & .75 & .09 & .12 \\
\hline 2008 & 3.75 & 3.72 & 51.35 & 37.0 & 279,868 & .42 & .19 & .09 & .74 & .09 & .11 \\
\hline 2009 & 3.74 & 3.71 & 50.29 & 36.9 & 275,452 & .42 & .20 & .09 & .74 & .09 & .12 \\
\hline 2010 & 3.82 & 3.79 & 60.65 & 37.6 & 285,290 & .42 & .20 & .10 & .73 & .09 & .14 \\
\hline 2011 & 3.77 & 3.71 & 50.04 & 37.7 & 301,267 & .42 & .20 & .10 & .73 & .09 & .14 \\
\hline 2012 & 3.62 & 3.57 & 51.95 & 37.9 & 305,850 & .42 & .21 & .11 & .72 & .09 & .14 \\
\hline 2013 & 3.46 & 3.42 & 53.23 & 38.0 & 314,823 & .42 & .21 & .11 & .72 & .09 & .14 \\
\hline 2014 & 3.34 & 3.31 & 55.53 & 38.1 & 327,713 & .42 & .22 & .12 & .71 & .09 & .14 \\
\hline 2015 & 3.26 & 3.26 & 56.57 & 38.2 & 430,919 & .41 & .22 & .11 & .71 & .09 & .14 \\
\hline 2016 & 3.22 & 3.14 & 59.28 & 38.3 & 351,216 & .41 & .23 & .12 & .70 & .10 & .13 \\
\hline
\end{tabular}

Note. Avg. $=$ average; GDP $=$ gross domestic product. Nonimplementing states are those other than Florida, Georgia, Maryland, Minnesota, Oklahoma, South Carolina, Tennessee, Texas, and West Virginia.

significantly associated with a decrease in the divorce rate. We then proceeded to run one regression with the dummy variable and the state-level predictors to see if any effects of simply having a policy remained after controlling for other predictors of divorce rates. All other models were run without the dummy variable. By default, the effectiveness of the implementation variable captures whether or not a state was an implementing state. Thus, we addressed issues of multicollinearity within the data.

Main analyses. Difference-in-difference estimation with state fixed effects was used to compare divorce rate trends among nonimplementing and implementing states. A series of robust fixed effects regressions were run to determine the relationship between implementing the policy and divorce rates (see Table 5). In the first regression model, only the implementing versus nonimplementing states dummy variable was included in the analysis. Results of this regression analysis (Model 1) showed a significant association between implementing a premarital education promotion policy and the divorce rate $(b=-.126, p<.001)$. In other words, policy implementation was associated with a .126-point decrease in the divorce rate.

A second robust fixed effects regression was run including all state-level control variables in the model to determine the relationship between implementing the policy and divorce rates after controlling for other known influences of divorce. Results of the second fixed effects estimation (Model 2) suggested that the as- sociation between divorce rates and simply having a policy was no longer significant after controlling for all state-level control variables $(b=-.336, p=.173)$. Three of the state-level control variables were significantly associated with the divorce rate: median household income $(b=-.021, p=.016)$, the percent of the population that is married $(b=6.373, p<.001)$, and the percent of the population that identified as Black ( $b=9.151, p=.014)$. No other state-level control variables were significantly associated with the divorce rate.

A third robust fixed effects regression model was run adding in variables that measured various features of the premarital education promotion policies. The dummy variable indicating implementing versus nonimplementing states was removed in this model. Again, the effectiveness of the implementation variable, which was included in this model, captures whether or not a state was an implementing state. Results of the third model (Model 3) showed that the three state-level control variables from the previous model remained significantly associated with slight shifts in coefficient sizes (see Table 5). Only the quality of implementation, or how effectively the bill was implemented, was significantly associated with the divorce rate $(b=-.528, p=.033)$. In other words, for every one-unit increase in the effectiveness of implementation there was a .528-point decrease in the divorce rate.

Model 4 reports associations with overall policy implementation when a linear time trend was included in the model to account for 


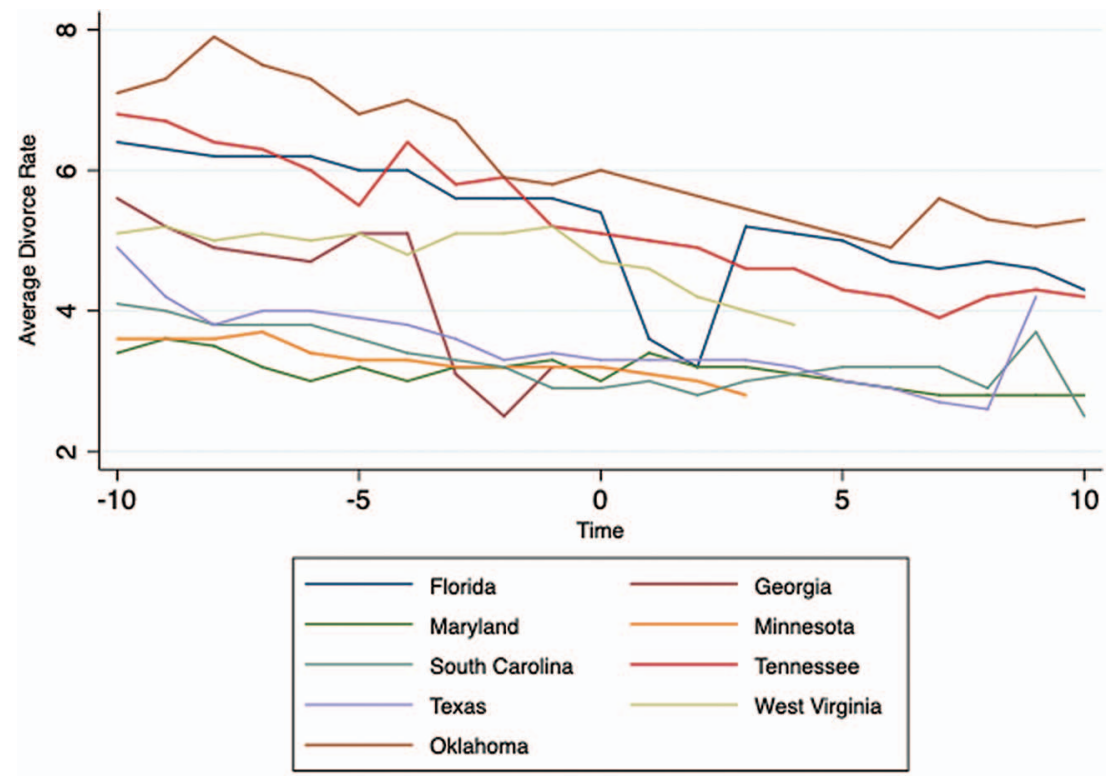

Figure 3. Average divorce rates in implementing states 10 years pre- and postimplementation. Georgia and Minnesota were missing at least 10 years of divorce rate data and Oklahoma was missing 5 years postimplementation due to changes in reporting requirements. See the online article for the color version of this figure.

the secular trend in divorce rates. No significant differences in the overall divorce rate were detected in connection with policy implementation once a linear time trend was included.

Finally, we estimated Model 1 and Model 2 using an event study approach where policy leads and lags were added to the model to determine whether policy "effects" were detected prior to policy implementation. Figure 4A (corresponding to Model 1) detects policy "effects" prior to policy implementation, a pattern not consistent with explaining findings as policy effects. When controlling for state-level demographic factors, Figure 4B (corresponding to Model 2) demonstrates a pattern of no policy effects prior to or following policy implementation. The analysis suggests that despite states' policy objectives to prevent divorce through incentivizing premarital education, we found no detectable effects of the policies up to 10 years following policy implementation.

Sensitivity analyses. California, Georgia, Hawaii, Indiana, Louisiana, and Minnesota were missing at least 10 years of divorce rate data and Oklahoma was missing five years due to changes in reporting requirements. Given that Georgia, Minnesota, and Oklahoma are policy-implementing states, we found it important to run a series of sensitivity analyses to confirm the results. Raw data for Oklahoma were obtained from the Department of Family Services and data for Minnesota were obtained from the Minnesota Judicial Branch. We replicated the methods used by NCHS to input missing divorce rate data for Oklahoma and Minnesota. Correlations between NCHS divorce rates and the raw divorce rates for Minnesota $(r=.74)$ and Oklahoma $(r=.67)$ were fairly high. Unfortunately, raw divorce rate data could not be collected from Georgia. All other missing data points remained.

An additional method was used to estimate the effects of the policy on the divorce rate. We interpolated missing data points by using ACS estimates of divorce rates for 2008 to 2016. Using available NCHS estimates and ACS estimates from 2008 to 2016, linear, quadratic, cubic, and log fit models were all tested. The linear fit estimate fit the data best.

We reran our previous analyses on these revised data sets. However, these models also failed to detect a significant effect on policy passage or policy implementation. (Details of these analyses are available upon request to Tiffany L. Clyde).

\section{Discussion}

\section{Implementation Study}

The purpose of the implementation study was to understand key features of each of the premarital education promotion policies and to document how well the policies were implemented in each state. Although the implementation study revealed slight variations among the statutes, they have much in common. The policies provide incentives, typically in the form of marriage license fee discounts, for couples who complete formal premarital education or counseling. Moreover, the policies stipulated a specific number of hours in formal premarital education, proof of meeting such requirements, and often the topics required to be covered in the premarital education course or counseling session. The policies also outlined requirements regarding the providers of premarital interventions. We uncovered some ambiguity in a few of the statutes, such as what kinds of premarital interventions meet the requirements.

This study also highlighted the variability in oversight and implementation of the policies. Although five states (Florida, Maryland, Tennessee, Texas, and West Virginia) appointed a formal entity responsible for oversight and implementation of the policy, our study revealed that little formal oversight actually occurred. Texas was the only implementing state that had formal oversight and funding (at least for a few years). The other four 


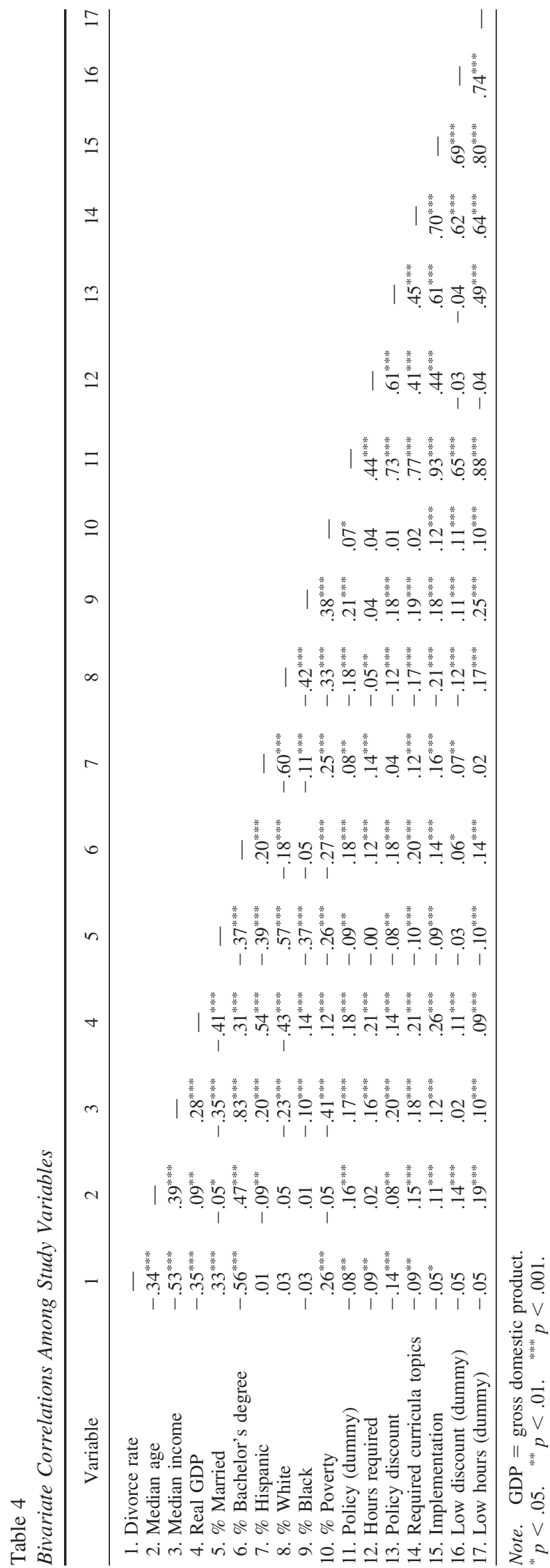

states appointed a government entity (e.g., circuit courts, administrative office of the courts) responsible for maintaining a roster of qualified providers. Sometimes this occurred and other times it did not. On the other hand, two states did not provide formal oversight of the legislation, but some minimal oversight did occur (Oklahoma, Tennessee). And some informal implementation efforts occurred in several states.

Overall, the implementation study highlights several weaknesses in the oversight and implementation of the policies. The purpose of a premarital education promotion policy is to strengthen the foundations of marriages to reduce divorce. Although simply passing legislation can send a significant signal about the value of effective preparation for marriage, still, the full impact of these policies is unlikely to be achieved without effective oversight and careful implementation. Although policy and program evaluation texts describe the need for high-quality policies and programs, they also strongly emphasize the challenge of proper and formal implementation (e.g., Bogenschneider, 2014). The results of our evaluation study document this challenge well.

\section{Evaluation Study}

To date, no research has documented whether the adoption of premarital education promotion policies has actually decreased the divorce rate in the implementing states. Our study sought to fill this empirical gap. The results of our extensive set of analyses converge to tell a similar story: Despite states' policy objectives to reduce divorce, we find no detectable effects on divorce rates as a result of policy initiation and implementation, especially after exploring linear time-trend models and an event-study approach where policy leads and lags were added to the model. It is unclear whether the absence of a connection between policy passage and changes in divorce rates results from poor implementation (i.e., a weak first stage of our logic model), no change in premarital education participation rates, or ineffectiveness of the premarital education interventions (i.e., a weak second stage of our logic model). Although we cannot separate the effects, past research on the difficulty of implementing policies (Pressman \& Wildavsky, 1973; Bardach, 1977), as well as past work documenting benefits associated with premarital education (Fawcett et al., 2010; Stanley et al., 2006; Nock et al., 2008) point to a weak first stage of the logic model. Alternative explanations of the null effect, however, should also be considered. Despite evidence of the positive effects of premarital education, there is still considerable variation in the quality of the wide variety of curricula and approaches to premarital education (Fawcett et al., 2010). Most programs are delivered in faith-based settings (Wilmoth \& Smyser, 2012) that may not use evidence-based curricula. One study of premarital programs provided by clergy documented mixed results in terms of including key components of effective programs (Wilmoth \& Smyser, 2012). If many couples are participating in programs that have little impact, then it is not surprising to see null effects. Clyde et al. (2019) argued that premarital education curricula may need considerable updating for the 21 st century to deal more effectively with dramatic shifts in relationship formation patterns and social changes. Perhaps policy efforts are currently stymied by participation in interventions that need improvements to address contemporary marital issues. 
Table 5

Fixed Effects Estimation Results

\begin{tabular}{|c|c|c|c|c|c|c|c|c|c|c|}
\hline \multirow[b]{2}{*}{ Variable } & \multicolumn{2}{|c|}{ Model 1} & \multicolumn{2}{|c|}{ Model 2} & \multicolumn{2}{|c|}{ Model 3} & \multicolumn{2}{|c|}{ Model 4} & \multicolumn{2}{|c|}{ Model 5} \\
\hline & $b$ & $S E$ & $b$ & $S E$ & $b$ & $S E$ & $b$ & $S E$ & $b$ & $S E$ \\
\hline Implementation policy & $-1.26^{\text {**** }}$ & .22 & -.34 & .24 & - & - & -.29 & .21 & -.26 & .20 \\
\hline Median age & & & -.04 & .02 & -.04 & .02 & & & .01 & .01 \\
\hline Median income & & & $-.02^{*}$ & .01 & $-.02^{*}$ & .01 & & & .02 & .01 \\
\hline Real GDP & & & $<.01$ & $<.01$ & $<.01$ & $<.01$ & & & .00 & .00 \\
\hline$\%$ Married & & & $6.37^{* * * *}$ & 1.59 & $5.86^{* * * * *}$ & 1.51 & & & 2.08 & 1.11 \\
\hline \% Bachelor's degree & & & -.78 & .56 & -.91 & .55 & & & $2.07^{* * * * *}$ & .57 \\
\hline \% Hispanic & & & -1.38 & 2.56 & -2.22 & 2.67 & & & -2.67 & 2.09 \\
\hline$\%$ White & & & 5.45 & 3.21 & 4.57 & 3.52 & & & 3.00 & 2.89 \\
\hline$\%$ Black & & & $9.15^{*}$ & 3.58 & $7.47^{*}$ & 3.51 & & & 5.64 & 3.14 \\
\hline$\%$ Poverty & & & 2.02 & 1.03 & 1.83 & 1.05 & & & $3.48^{* * * *}$ & .98 \\
\hline Hours required & & & & & .35 & .43 & & & & \\
\hline Discount & & & & & .35 & .31 & & & & \\
\hline Total curriculum & & & & & .13 & .07 & & & & \\
\hline Implemented effectiveness & & & & & $-.53^{* * * *}$ & .24 & & & & \\
\hline Low discount $(<\$ 47.50)$ & & & & & .01 & .57 & & & & \\
\hline Low hours $(1-7)$ & & & & & - & - & & & & \\
\hline Linear time trend & $\mathrm{N}$ & & & & & & & & $\mathrm{Y}$ & \\
\hline$R^{2}$ & .1 & & & & & & & & 6 & \\
\hline
\end{tabular}

Note. $\mathrm{GDP}=$ gross domestic product.

${ }^{*} p<.05 . \quad{ }^{* * *} p<.01 .{ }^{* * *} p<.001$

\section{Implications for Policy and Research}

The findings of the implementation and evaluation studies have noteworthy implications for policymakers and scholars. Results of the evaluation study showed no effect on the divorce rate in response to premarital education promotion policies. Given the extensive research documenting the negative effects of divorce on children and adults (Amato, 2000; Amato \& Anthony, 2014; McLanahan et al., 2013) and the effects of family instability on taxpayers and society (Scafidi, 2008; Schramm, 2006), the findings of this study will be disappointing to some. Nevertheless, the findings still have several implications for these policies.
Clearly, the documented weakness in implementation efforts suggests that legislators should focus greater attention on effective implementation, the first stage of our logic model. For implementing states, additional efforts should be made to increase effectiveness to reap the maximum benefits of the policies. These efforts could include exploring alternative incentives to the marriage license to benefit more couples, assigning an entity responsible for the oversight, quality assurance, and implementation, including advertising and increasing awareness, approving curricula, and creating and maintaining a roster of qualified providers. In addition, implementing states should allocate appropriate funding to help with the oversight and implementation of the policies. Formative and outcome evaluations should be
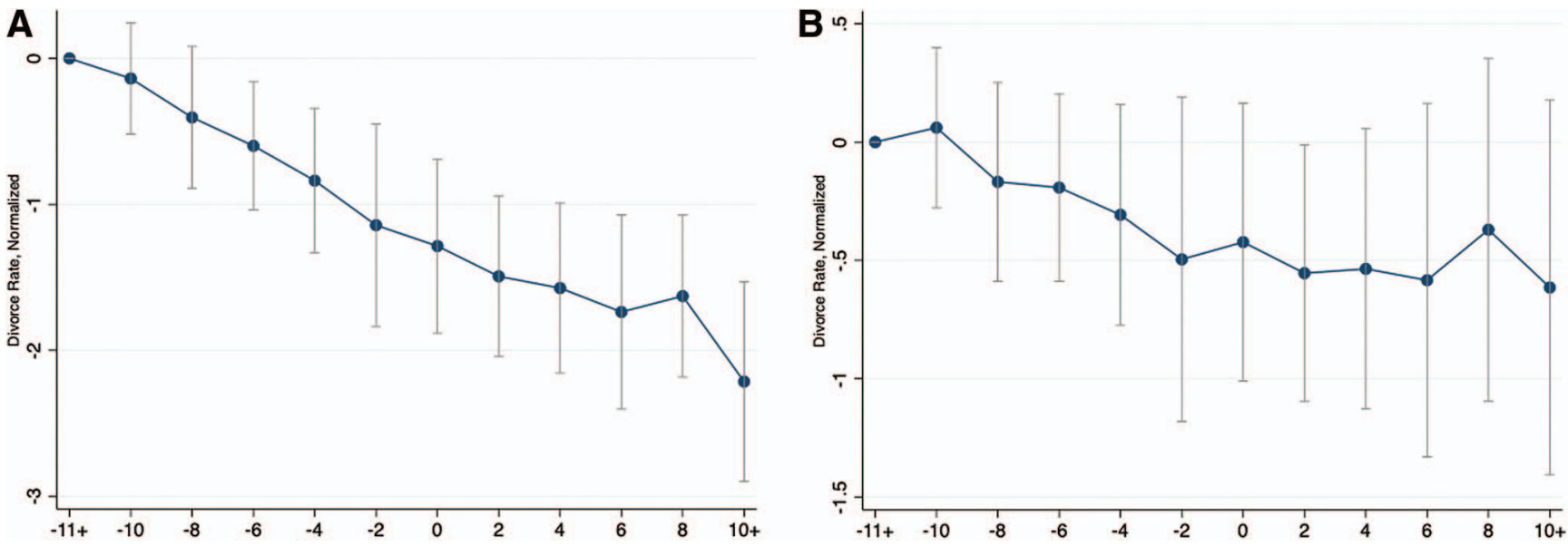

Figure 4. Estimated trends in annual divorce rates in implementing states before and after premarital policy implementation. Divorce rates indexed to levels 10 years prior to policy implementation. Georgia and Minnesota were missing at least 10 years of divorce rate data and Oklahoma was missing 5 years postimplementation divorce-rate data due to changes in reporting requirements. A: No demographic controls; B: Demographic controls. See the online article for the color version of this figure. 
conducted as part of this process. These evaluations can highlight weaknesses in the premarital education offerings and the policies that can lead to appropriate changes in order to help the policy achieve its intended goals. Again, it is hypothesized that effective implementation will lead to greater awareness, availability, and participation in premarital education (the first stage), thereby strengthening marital relationships and reducing divorce (the second stage; Fawcett et al., 2010; Stanley, Amato, et al., 2006; Nock et al., 2008).

Recognizing some of the apparent weaknesses in previous policies and their implementation, Utah policymakers have made specific efforts to improve their policy and achieve the desired results. This is reflected both in legislative language of the 2018 bill and subsequent (and ongoing) efforts to implement the policy. First, Utah's legislation appointed the Utah Marriage Commission several responsibilities, including promoting the policy, promoting and assisting in the offerings of premarital counseling and education services, approving online courses and face-to-face premarital counseling and education services, and evaluating the effectiveness of the policy. One county in Utah is has developed an online marriage application system which will be operational October 1, 2020. (Couples who want to apply for a discount must do so online. Any couple, regardless of where they marry in Utah, can apply online through this county's portal).

The Utah Marriage Commission is codified in statute and has a 21-year history. The commission is implementing an extensive marketing campaign to make couples aware of the discount option and how to take advantage of it. The commission also contracted with the ePREP online relationship education program providers to offer free vouchers to Utah engaged couples to participate in this online, evidence-based program (Braithwaite \& Fincham, 2009, 2011). This will open up services to those who cannot find a local, face-to-face provider, or who prefer a more private approach to premarital education. Also, the Commission has worked with the wedding industry retailers across the state to agree to provide product and service discounts to couples who invest in formal premarital education, multiplying the effect of the marriage license discount. In addition, Utah's legislation made the policy and implementation work self-sustaining: $\$ 20$ of the marriage license fee from couples who do not participate in premarital education or counseling goes to fund the Utah Marriage Commission that oversees policy implementation. Other states may want to consider this model, or various aspects of it, for improving their policies and implementation as well as reducing the fiscal cost of the policy for states and taxpayers.

Policymakers may also want to consider additional models for effective policy implementation and evaluation. One notable example is the Community Juvenile Accountability Act (CJAA) that the Washington State Legislature passed in 1997. The legislature worked with the Washington State Institute for Public Policy, which provided evaluations of programs and policy recommendations (see Aos, Miller, \& Drake, 2006, for a description of the legislation and directive for the Institute). Four research-based programs were selected and implemented by the juvenile courts and the state Juvenile Rehabilitation Administration (JRA), who then received appropriate funding from the legislature. The JRA was responsible for statewide training and ensuring program fidelity. The legislation required formative and outcome evaluations of the programs to ensure program fidelity. One program was the Functional Family Therapy Program (see Barnoski, 2002, for an in-depth description of program implementation). A 5-year program evaluation of the Functional Family Therapy Program conducted by the Institute revealed that the program reduced recidi- vism by as much as $30 \%$ when it was delivered by trained therapists (Barnoski, 2002). However, 47\% of therapists in the program were rated as less competent and had no effect with their clients (Barnoski, 2002). Based on these findings, Washington has implemented a quality assurance process when new programs are implemented. The Washington State Institute for Public Policy provides a variety of resources on their website for quality assurance of state implementation of policies and programs. Again, policymakers may want to consider this example, or various aspects of it, for improving their policies and implementation.

Although this study begins to fill a gap in the research about the effectiveness of premarital education promotion policies for reducing early divorce rates in the United States, several areas of research need to be pursued. First, our measure of divorce is an overall divorce rate, not just newlyweds, which is less sensitive to treatment or policy effects. That is, many, if not most, longer-married married couples in the population were not exposed to the treatment. Unfortunately, data on divorce rates for couples in the early years of marriage is hard to find. Having information on divorce rates just for couples in the high-risk divorce years would allow for more precision in estimating the effects of the policy. In addition, there is some research to suggest that legal separation is a strong indicator of divorce (Stanley, 2001). However, data on legal separation is not gathered in any formal manner at this time. Future research should include measures of legal separation in order to assess the policies full effects.

Moreover, this study was not able to document whether the policies have actually resulted in increased participation rates in premarital education or counseling, a key hypothesized mechanism for achieving the policy goal. Future research should explicitly document this chain of increased participation leading to better preparation for marriage and ultimately to reduced divorce rates. In addition, several important factors could moderate the effectiveness of these policies. For instance, it would be valuable to assess the effects of the policy on couples getting married at younger versus older ages. When couples are less mature, involvement in premarital interventions may be more important. States with larger proportions of couples marrying at earlier ages may benefit the most from these policies. Other demographic factors, such as socioeconomic disadvantage and first versus second marriages, also may impact the effectiveness of premarital education promotion policies, because these couples are at higher risk for divorce. Finally, future research should document other potential outcomes of policy interest that could be associated with greater participation in premarital interventions, such as reducing domestic violence and increasing gender equality.

In summary, past research has documented the effectiveness of premarital education programs (Fawcett et al., 2010; Nock et al., 2008; Stanley, Amato, et al., 2006), including reduced early divorce risk, but only a minority of couples invest in them. Ten states have implemented policy efforts to try to take the potential benefits of premarital education to scale. But benefits seen in individual programs do not guarantee the same benefits will be realized in scaled-up programming (Barnoski, 2002). And program evaluation studies cannot speak directly to whether policies to disseminate programs actually work; policy-level evaluations are necessary for this (Hawkins, Amato, \& Kinghorn, 2013). This policy-level evaluation study attempted to examine whether state laws to incent participation in premarital education have produced an intended, key outcome: reduced divorce rates. Although there were limitations to this study and more research is needed, the early evidence is that the policies have 
not impacted divorce rates. General poor implementation of the policies is a likely contributor to the null effects. Policymakers should give greater attention to effective implementation of premarital education promotion policies to ascertain if they can decrease early divorce rates. And program developers may need to update and strengthen their programs for contemporary couples.

\section{References}

Allison, P. (2012, September 10). When can you safely ignore multicollinearity? Statistical Horizons. Retrieved from http://statisticalhorizons .com/multicollinearity

Amato, P. R. (1996). Explaining the intergenerational transmission of divorce. Journal of Marriage and the Family, 58, 628-640. http://dx .doi.org/10.2307/353723

Amato, P. R. (2000). Consequences of divorce for adults and children. Journal of Marriage and the Family, 62, 1269-1287. http://dx.doi.org/ 10.1111/j.1741-3737.2000.01269.x

Amato, P. R. (2010). Research on divorce: Continuing trends and new developments. Journal of Marriage and Family, 72, 650-666. http://dx .doi.org/10.1111/j.1741-3737.2010.00723.x

Amato, P. R. (n.d.). Interpreting divorce rates, marriage rates, and data on the percentage of children with single parents. Oklahoma City, OK: National Healthy Marriage Resource Center. Retrieved from https:// www.healthymarriageinfo.org/wp-content/uploads/2017/12/Inter preting-Divorce-Rat.pdf

Amato, P. R., \& Afifi, T. D. (2006). Feeling caught between parents: Adult children's relations with parents and subjective well-being. Journal of Marriage and Family, 68, 222-235. http://dx.doi.org/10.1111/j.17413737.2006.00243.x

Amato, P. R., \& Anthony, C. J. (2014). Estimating the effects of parental divorce and death with fixed effects models. Journal of Marriage and Family, 76, 370-386. http://dx.doi.org/10.1111/jomf.12100

Amato, P. R., \& Cheadle, J. (2005). The long reach of divorce: Divorce and child well-being across three generations. Journal of Marriage and Family, 67, 191-206. http://dx.doi.org/10.1111/j.0022-2445.2005 .00014.x

Amato, P. R., \& Keith, B. (1991). Parental divorce and the well-being of children: A meta-analysis. Psychological Bulletin, 110, 26-46. http:// dx.doi.org/10.1037/0033-2909.110.1.26

Amato, P. R., \& Sobolewski, J. M. (2001). The effects of divorce and marital discord on adult children's psychological well-being. American Sociological Review, 66, 900-921. http://dx.doi.org/10.2307/3088878

Aos, S., Miller, M., \& Drake, E. (2006). Evidence-based public policy options to reduce future prison construction criminal justice costs, and crime rates. Olympia, WA: Washington State Institute for Public Policy.

Bardach, E. (1977). The implementation game: What happens after a bill becomes a law. Cambridge, MA: MIT Press.

Barnoski, R. (2002). Washington state's implementation of functional family therapy for juvenile offenders: Preliminary findings. Olympia, WA: Washington State Institute for Public Policy.

Berk, L. E. (2000). Child development (5th ed.). Boston, MA: Ally and Bacon.

Birch, P. J., Weed, S. E., \& Olsen, J. (2004). Assessing the impact of community marriage policies on county divorce rates. Family Relations, 53, 495-503. http://dx.doi.org/10.1111/j.0197-6664.2004.00058.x

Bogenschneider, K. (2014). Family policy matters: How policymaking affects families and what professional can do. New York, NY: Routledge. http://dx.doi.org/10.4324/9780203753200

Booth, A., \& Amato, P. R. (2001). Parental predivorce relations and offspring postdivorce well-being. Journal of Marriage and the Family, 63, 197-212. http://dx.doi.org/10.1111/j.1741-3737.2001.00197.x

Braithwaite, S. R., \& Fincham, F. D. (2009). A randomized clinical trial of a computer based preventive intervention: Replication and extension of
ePREP. Journal of Family Psychology, 23, 32-38. http://dx.doi.org/10 1037/a0014061

Braithwaite, S. R., \& Fincham, F. D. (2011). Computer-based dissemination: A randomized clinical trial of ePREP using the actor partner interdependence model. Behaviour Research and Therapy, 49, 126-131. http://dx.doi.org/10.1016/j.brat.2010.11.002

Bronfenbrenner, U. (1979). The ecology of human development: Experiments by nature and design. Cambridge, MA: Harvard University Press.

Bronfenbrenner, U. (1992). Ecological systems theory. London, U.K. Jessica Kingsley Publishers.

Brotherson, S. E., \& Duncan, W. C. (2004). Rebinding the ties that bind: Government efforts to preserve and promote marriage. Family Relations: An Interdisciplinary Journal of Applied Family Studies, 53, 459468. http://dx.doi.org/10.1111/j.0197-6664.2004.00054.x

Brotherson, S. E., \& Teichert, J. B. (2001). Value of the law in shaping social perspectives on marriage. Journal of Law \& Family Studies, 3 , 23-56.

Centers for Disease Control and Prevention. (2017). Key statistics from the National Survey of Family Growth-D Listing. Retrieved from https:// www.cdc.gov/nchs/nsfg/key_statistics/d.htm\#divorce

Clyde, T. L., Hawkins, A. J., \& Willoughby, B. J. (2019). Revising premarital relationship interventions for the next generation. Journal of Marital and Family Therapy. Advance online publication. http://dx.doi .org/10.1111/jmft.12378

Copen, C. E., Daniels, K., Vespa, J., \& Mosher, W. D. (2012). First marriages in the United States: 2006-2010 National Survey of Family Growth (No. 49). Wasghinton, DC: U. S. Department of Health and Human Services, Centers for Disease Control and Prevention, National Center for Health Statistics.

Divorce Source.com. (n.d.). Separation or waiting periods for no fault divorce. Retrieved from https://www.divorcesource.com/ds/divorcepro cess/separation-or-waiting-periods-for-no-fault-divorce-621.shtml

Elliot, D. B., Simmons, T., \& Lewis, J. M. (2010). Evaluation of marital event items on the ACS. Retrieved from http://citeseerx.ist.psu.edu/ viewdoc/download;jsessionid $=8$ BA059583291281599F40EDB 43 $37 \mathrm{CC} 2 \mathrm{~A}$ ?doi $=10 \cdot 1 \cdot 1 \cdot 224.9479 \& \mathrm{rep}=$ rep $1 \&$ type $=$ pdf

Fawcett, E. B., Hawkins, A. J., Blanchard, V. L., \& Carroll, J. S. (2010). Do premarital education programs really work? A meta-analytic study. Family Relations: An Interdisciplinary Journal of Applied Family Studies, 59, 232-239. http://dx.doi.org/10.1111/j.1741-3729.2010.00598.x

Flood, S., King, M., Rodgers, R., Ruggles, S., \& Warren, J. R. (2018). Integrated Public Use Microdata Series, Current Population Survey: Version 6.0 [dataset]. Minneapolis, MN: University of Minnesota.

Frisco, M. L., Müller, C., \& Frank, K. (2007). Parents' union dissolution and adolescents' school performance: Comparing methodological approaches. Journal of Marriage and Family, 69, 721-741. http://dx.doi .org/10.1111/j.1741-3737.2007.00402.x

Gallagher, M. (2004). Can government strengthen marriage? Evidence from the social sciences. New York, NY: Institute for American Values.

Gueron, J. M., \& Rolston, H. (2013). Fighting for reliable evidence. New York, NY: Russell Sage Foundation.

Haskins, R., \& Margolis, G. (2015). Show me the evidence: Obama's fight for rigor and results in social policy. Washington, DC: Brookings Institution.

Hawkins, A. J. (2015). Does it work? Effectiveness research on relationship and marriage education. In J. Ponzetti (Ed.), Evidence-based approaches to relationship and marriage education (pp. 60-73). New York, NY: Routledge.

Hawkins, A. J. (2019). Are federally-supported relationship education programs for lower income individuals and couples working? A review of evaluation research. Washington, DC: American Enterprise Institute. Retrieved from https://www.aei.org/research-products/report/arefederally-supported-relationship-education-programs-for-lower-incomeindividuals-and-couples-working-a-review-of-evaluation-research/ 
Hawkins, A. J., Amato, P. R., \& Kinghorn, A. (2013). Are governmentsupported healthy marriage initiatives affecting family demographics? A state-level analysis. Family Relations: An Interdisciplinary Journal of Applied Family Studies, 62, 501-513. http://dx.doi.org/10.1111/fare 12009

Hawkins, A. J., Blanchard, V. L., Baldwin, S. A., \& Fawcett, E. B. (2008). Does marriage and relationship education work? A meta-analytic study. Journal of Consulting and Clinical Psychology, 76, 723-734. http://dx .doi.org/10.1037/a0012584

Hawkins, A. J., Stanley, S. M., Blanchard, V. L., \& Albright, M. (2012). Exploring programmatic moderators of the effectiveness of marriage and relationship education programs: A meta-analytic study. Behavior Therapy, 43, 77-87. http://dx.doi.org/10.1016/j.beth.2010.12.006

Hawkins, A. J., \& VanDenBerghe, B. (2014). Facilitating forever: A feasible public policy agenda to help couples form and sustain healthy relationships and enduring marriages. Charlottesville, VA: National Marriage Project, University of Virginia.

James, S. L. (2015). Variation in marital quality in a national sample of divorced women. Journal of Family Psychology, 29, 479-489. http:// dx.doi.org/10.1037/fam0000082

Kennedy, S., \& Ruggles, S. (2014). Breaking up is hard to count: The rise of divorce in the United States, 1980-2010. Demography, 51, 587-598. http://dx.doi.org/10.1007/s13524-013-0270-9

Kreider, R. M., \& Ellis, R. (2011). Number, timing, and duration of marriages and divorces: 2009. U.S. Department of Commerce, Economics and Statistics Administration, U.S. Census Bureau, or Current Population Reports, P70-125. Washington, DC: U.S. Census Bureau.

Larson, J. H., Newell, K., Topham, G., \& Nichols, S. (2002). A review of three comprehensive premarital assessment questionnaires. Journal of Marital and Family Therapy, 28, 233-239. http://dx.doi.org/10.1111/j .1752-0606.2002.tb00360.x

Lavner, J. A., Bradbury, T. N., \& Karney, B. R. (2012). Incremental change or initial differences? Testing two models of marital deterioration. Journal of Family Psychology, 26, 606-616. http://dx.doi.org/10 $.1037 / \mathrm{a} 0029052$

Lavner, J. A., Karney, B. R., \& Bradbury, T. N. (2012). Do cold feet warn of trouble ahead? Premarital uncertainty and four-year marital outcomes. Journal of Family Psychology, 26, 1012-1017. http://dx.doi.org/10 $.1037 / \mathrm{a} 0029912$

Lee, J. (2013). The impact of mandatory cooling-off period on divorce. The Journal of Law \& Economics, 56, 227-243. http://dx.doi.org/10.1086/ 667710

McLanahan, S., Tach, L., \& Schneider, D. (2013). The causal effects of father absence. Annual Review of Sociology, 39, 399-427. http://dx.doi .org/10.1146/annurev-soc-071312-145704

Michon, K. (n.d.). How much will my divorce cost and how long will it take? Retrieved from https://www.nolo.com/legal-encyclopedia/ctp/ cost-of-divorce.html

National Marriage Project. (2019). The state of unions: 2019. Charlottesville, VA: The National Marriage Project and School of Family Life, Brigham Young University.

Nock, S. L., Sanchez, L. A., \& Wright, J. D. (2008). Covenant marriage: The movement to reclaim tradition in America. New Brunswick, NJ: Rutgers University.

Ooms, T. (1998). Toward more perfect unions: Putting marriage on the public agenda. Washington, DC: Family Impact Seminar.

Pew Research Center. (2017, July 7). U.S. divorce rate dips, but moral acceptability hits new high. Retrieved from https://news.gallup.com/poll/ 213677/divorce-rate-dips-moral-acceptability-hits-new-high.aspx

Pressman, J. L., \& Wildavsky, A. B. (1973). Implementation. Berkeley, CA: University of California Press.
Prochaska, J. O., DiClemente, C. C., \& Norcross, J. C. (1992). In search of how people change. Applications to addictive behaviors. American Psychologist, 47, 1102-1114. http://dx.doi.org/10.1037/0003-066X.47.9 .1102

Randles, J. (2017). Proposing prosperity?: Marriage education policy and income inequality in America. New York, NY: Columbia University.

Rosa, E. M., \& Tudge, J. (2013). Urie Bronfenbrenner's theory of human development: Its evolution from ecology to bioecology. Journal of Family Theory \& Review, 5, 243-258. http://dx.doi.org/10.1111/jftr .12022

Sawhill, I. V. (2014). Generation unbound: Drifting into sex and parenthood without marriage. Washington, DC: Brooking Institution.

Scafidi, B. (2008). The taxpayer costs of divorce and unwed childbearing. Institute for American Values, 12, 13.

Schramm, D. G. (2006). Individual and social costs of divorce in Utah Journal of Family and Economic Issues, 27, 133-151. http://dx.doi.org/ 10.1007/s10834-005-9005-4

Schramm, D. G., Harris, S. M., Whiting, J. B., Hawkins, A. J., Brown, M., \& Porter, R. (2013). Economic costs and policy implications associated with divorce: Texas as a case study. Journal of Divorce \& Remarriage, 54, 1-24. http://dx.doi.org/10.1080/10502556.2012.725354

Stanley, S. M. (2001). Making a case for premarital education. Family Relations: An Interdisciplinary Journal of Applied Family Studies, 50, 272-280. http://dx.doi.org/10.1111/j.1741-3729.2001.00272.x

Stanley, S. M., Amato, P. R., Johnson, C. A., \& Markman, H. J. (2006). Premarital education, marital quality, and marital stability: Findings from a large, random household survey. Journal of Family Psychology, 20, 117-126. http://dx.doi.org/10.1037/0893-3200.20.1.117

StataCorp. (2017). Stata statistical software: Release 15. College Station, TX: StataCorp, LLC.

Waite, L., \& Gallagher, M. (2002). The case for marriage: Why married people are happier, healthier and better off financially. New York, NY: Broadway Books.

Wilcox, W. B. (2009). The evolution of divorce. National Affairs, 1, $81-94$.

Williamson, H. C., Hammett, J. F., Ross, J. M., Karney, B. R., \& Bradbury, T. N. (2018). Premarital education and later relationship help-seeking. Journal of Family Psychology, 32, 276-281. http://dx.doi.org/10.1037/ fam0000383

Williamson, H. C., Karney, B. R., \& Bradbury, T. N. (2019). Barriers and facilitators of relationship help-seeking among low-income couples. Journal of Family Psychology, 33, 234-239. http://dx.doi.org/10.1037/ fam0000485

Williamson, H. C., Trail, T. E., Bradbury, T. N., \& Karney, B. R. (2014), Does premarital education decrease or increase couples' later helpseeking? Journal of Family Psychology, 28, 112-117. http://dx.doi.org/ 10.1037/a0034984

Wilmoth, J. D., \& Smyser, S. (2012). A national survey of marriage preparation provided by clergy. Journal of Couple \& Relationship Therapy, 11, 69-85. http://dx.doi.org/10.1080/15332691.2012.639705

Wolfers, J. (2006). Did unilateral divorce laws raise divorce rates? A reconciliation and new results. The American Economic Review, 96, 1802-1820. http://dx.doi.org/10.1257/aer.96.5.1802

Wolfinger, N. H. (2005). Understanding the divorce cycle: The children of divorce in their own marriages. Cambridge, U. K.: Cambridge University Press. http://dx.doi.org/10.1017/CBO9780511499616

Received September 9, 2019

Revision received October 28, 2019 Accepted October 31, 2019 